\title{
LIBERDADE E SERVIDÃO ENTRE O HUMANISMO \\ E A REFORMA: Um enfoque acerca das experiências de subjetividade na cultura do Renascimento
}

\section{Dissertação de Mestrado}

Dissertação apresentada como requisito parcial para obtenção do grau de Mestre pelo Programa de PósGraduação em História Social da Cultura, do Departamento de História da PUC-Rio.

Orientador: Prof.Antonio Edmilson Martins Rodrigues 
Todos os direitos reservados, é proibida a reprodução total ou parcial do trabalho sem autorização da Universidade do autor e do orientador.

\section{Sergio Xavier Gomes de Araújo}

Graduou-se em História na Universidade Federal Fluminense (UFF) em 2001, e ingressou no curso de mestrado da Pontificia Universidade Católica do Rio de Janeiro (PUC) em 2002.

Ficha Catalográfica

Araújo, Sergio Xavier Gomes de

Liberdade e servidão entre o humanismo e a reforma : um enfoque acerca das experiências de subjetividade na cultura do renascimento / Sergio Xavier Gomes de Araújo ; orientador: Antonio Edmilson M. Rodrigues. - Rio de Janeiro : PUC-Rio, Departamento de História, 2005.

127 f. ; $30 \mathrm{~cm}$

Dissertação (mestrado) - Pontifícia Universidade Católica do Rio de Janeiro, Departamento de História.

Inclui referências bibliográficas.

1. História - Teses. 2. Renascimento. 3. Humanismo. 4. Reformas religiosas. 5. Livre arbítrio. 6. Pico della Mirandola, Giovanni, 1463-1497. 7. Erasmus, Desiderius, 1467?-1536. 8. Lutero, Martinho, 1483-1546. I. Rodrigues, Antonio Edmilson M. II. Pontifícia Universidade Católica do Rio de Janeiro. Departamento de História. III. Título. 


\section{Sergio Xavier Gomes de Araújo}

\section{LIBERDADE E SERVIDÃO ENTRE O HUMANISMO \\ E A REFORMA: Um enfoque acerca das experiências de subjetividade na cultura do Renascimento}

Dissertação apresentada como requisito parcial para obtenção do grau de Mestre pelo Programa de PósGraduação em História Social da Cultura do Departamento de História do Centro de Ciências Sociais da PUC-Rio. Aprovada pela Comissão Examinadora abaixo assinada.

Prof' Antonio Edmilson Martins Rodrigues

Orientador Departamento de História-PUC-Rio

Profo Rodrigo Nunes Bentes Monteiro Departamento de História - UFF

Prof ${ }^{\circ}$ Danilo Marcondes de Souza Filho

Departamento de Filosofia - PUC-Rio

\section{Prof' João Pontes Nogueira}

Vice-Decano de Pós-Graduação do Centro de Ciências Sociais

PUC-Rio

Rio de Janeiro, 29 de junho de 2004. 


\section{AGRADECIMENTOS}

Agradeço à CAPES por ter me concedido a bolsa de estudos, que foi indispensável para a realização deste trabalho.

Agradeço também aos meus pais desde sempre pela força e pelo apoio.

Ao meu orientador Antonio Edmilson M. Rodrigues, com quem sempre me foi tão enriquecedor e estimulante trabalhar, e ao Prf. Ricardo Benzaquen de Araújo pelas preciosas sugestões e indicações, que foram fundamentais para o texto.

A Fabrina Magalhães, por sua sempre maravilhosa presença ao meu lado, e pela ajuda indispensável neste tema que sempre lhe foi tão caro, a cultura humanista e a obra de Erasmo de Rotterdã.

Aos meus colegas do mestrado Felipe Charbel, Danrley, Affonso, Renata, Luísa e Maria Eugênia, que fizeram deste um tempo inesquecível.

Ao amigo Felipe Chen de Almeida que me acompanha desde meus tempos da graduação na UFF, pelo estímulo e pela força. 


\section{RESUMO}

Araújo, Sergio Xavier Gomes de; Rodrigues, Antonio Edmilson Martins. Liberdade e Servidão entre o Humanismo e a Reforma: um enfoque acerca das experiências de subjetividade na cultura do Renascimento. Rio de Janeiro, 2004, 125p. Dissertação de Mestrado - Departamento de História. Pontifícia Universidade Católica do Rio de Janeiro.

O trabalho pretende lançar uma luz sobre o início dos tempos modernos abordando a riqueza das experiências de subjetividade na cultura renascentista. Suas complexidades são tematizadas no exame das complicadas relações entre o ideário humanista e o movimento das reformas religiosas, e suas respectivas evoluções. Destaca-se primeiro, nos primórdios da Renascença, um impulso pela interiorização do sentimento religioso, que aliado ao resgate dos valores da Antiguidade, se faz cerne do anseio por um cristianismo renovado, centrado na valorização do homem e do mundo, do poder do espírito em alcançar a salvação, sem a intermediação das instituições da Igreja. O movimento das reformas religiosas, fundado no anseio renovador humanista de homens como Nicolau de Cusa, Pico Della Mirandola e Erasmo de Rotterdã, não tardará entretanto em se apartar dele a partir de Lutero, numa religiosidade que condena o espírito humano e sua experiência mundana. $\mathrm{O}$ exame da discussão sobre o livre arbítrio entre Erasmo e Lutero nos mostra o embate entre duas concepções distintas sobre o homem, que surtirão conseqüências, não raro, inesperadas sobre a formação do mundo moderno.

\section{Palavras-chave}

Renascimento; Humanismo; reformas religiosas; Pico Della Mirandola; Erasmo de Rotterdã; Lutero; livre arbítrio. 


\section{ABSTRACT}

Araújo, Sergio Xavier Gomes de; Rodrigues, Antonio Edmilson Martins. Freedom and Servitude between Humanism and Reformation: a perspective about the subjectivity experiences in Renaissance culture. Rio de Janeiro, 2004, 125p. MSc. Dissertation - Departamento de História. Pontifícia Universidade Católica.

The study wants to iluminate the begining of modern times treating the richness of the subjectivity experiences in Renaissance culture. The complexities of that should be look in the analysis of the complicated relations between the humanistic ideals and the religious reformations movements and his respective evolutions. First, in the relief, emerges in primeval Renaissance, a impulse for interiozation of religious sentiment, which, in alliance with the rescue of the values of the Antiquity, makes itself in the roots of a new cristianity, centralize in the valorization of man and the world, in the power of the spirity in reaching the salvation, without the intermediation of institutions of the Church. The religious reformations movements, first in the roots of the humanistic renovator impulse of men like Nicholas de Cusa, Pico Della Mirandola and Erasmo de Rotterdã, should be, in a second time, aparted of him, since Lutero and his religious sentiment which condemn the human spirity and his mundane experience. The analyses of the discussion about the free arbitre between Erasmo and Lutero shows to us the confrontation of two diferent conceptions of man, which have their impact, many times imprevisible, in the formation of modern times.

\section{KEYWORDS}

Renaissance; Humanism; religious reformations; Pico Della Mirandola; Erasmo de Rotterdã; Luther; free arbitre. 


\section{SUMÁRIO}

1. Introdução

2. Neoplatonismo renascentista Pico Della Mirandola

e o Discurso Sobre a Dignidade do Homem 13

2.1. Nicolau de Cusa 19

2.2. Marsilio Ficino 23

2.3. Pico Della Mirandola e o

Discurso Sobre a Dignidade do Homem 27

2.3.1. Pico e a Astrologia $\quad 37$

2.3.2. Dignidade do Homem

e uma nova apologética do cristianismo $\quad 41$

3. Erasmo e o Essai sur le libre Arbitre 43

3.1. Erasmo e Lutero:

a busca pela renovação da fé cristã 43

3.2. Formação intelectual e religiosa de Erasmo 54

3.3. A filosofia cristã 58

3.4. O Essai sur le libre Arbitre 60

4. Lutero e o Du Serf Arbitre 77

4.1. A crise espiritual de Lutero e os princípios de sua nova teologia: a natureza decaída do homem e a justificação pela fé $\quad 77$

4.2. As vias da ruptura com a Igreja 82

4.3. Doutrina luterana e o servo arbítrio 92

4.3.1. Formação religiosa de Lutero 96

4.3.2. O sevo arbítrio e a visão luterana do mundo 102

4.3.3. O servo arbítrio, a Reforma e o Humanismo 111

5. Conclusão 119

6. Referências bibliográficas 124 